\title{
SOCIALIZATION OF POLICY ALTERNATIVE MODELS IN EFFORTS OF HANDLE COVID-19 PANDEMIC PROBLEMS IN YOSOREJO VILLAGE, METRO CITY
}

\author{
Yuditya Wardhana \\ Sekolah Tinggi ILmu Sosial dan Ilmu Politik Dharma Wacana, Lampung, Indonesia \\ yuditya5290@gmail.com
}

\begin{abstract}
Various policies have been issued by the government in an effort to break the chain of spreading COVID-19 cases in Indonesia. However, from a number of policies that have been issued, until now there has been no decrease in the number of positive cases of COVID-19, even every day the number of confirmed positive cases is increasing and the spread is increasingly widespread in various regions in Indonesia. The goal to be achieved in this community service activity is as a form of introducing and providing understanding to the public about alternative policy models in overcoming the COVID19 problem. The service was carried out on Monday, August 31, 2020 in Yosorejo Village, East Metro District, Metro City. This activity took place in the form of socialization and discussions with the local community. The result of this activity is the achievement of goals and benefits in community service activities.
\end{abstract}

Keywords: Public Policy, Alternative Policy, COVID-19 Pandemic.

\section{A. Introduction}

At the beginning of 2020, the world was shocked with a serious infectious disease of unknown cause. The World Health Organization (WHO) received a report from China that there were dozens of acute pneumonia patients in the city of Wuhan, Hubei Province, China, to be precise on the last day of 2019. On January 10, 2020 the cause began to be identified and the genetic code was obtained, namely the virus. new corona virus, and at the end of January 2020
WHO determined the Global Emergency status for this Corona virus case and named it Corona Virus Disease-19 (COVID-19) on February 11, 2020. (Handayani, 2020)

The first case reported in Indonesia was on March 2, 2020. Cases of the spread of COVID-19 have continued to increase and have spread to various regions in Indonesia very quickly. Up to 22 August 2020, the National Disaster Management Agency (BNPB) reported 
151,498 confirmed cases of COVID-19 with 6,594 deaths.

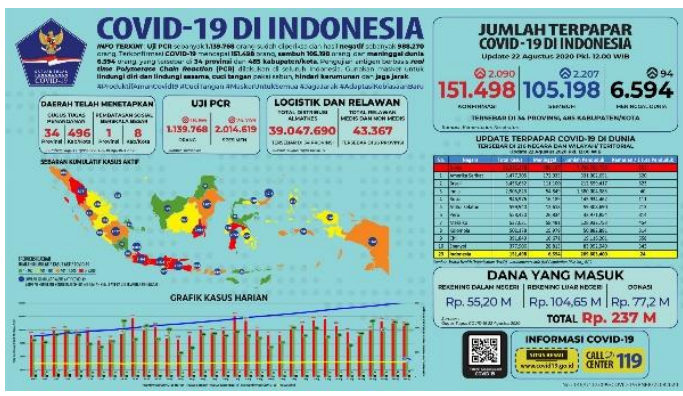

Figure 1. Infographics Update on Covid -19 Cases in Indonesia

Source: https://www.bnpb.go.id/ accessed on 22 August 2020 at 19:45 WIB.

Until now, the government has issued various policies in an effort to deal with the COVID-19 pandemic problem in Indonesia. Among these policies are: KEPPRES No. 11/2020 concerning Determination of Public Health Emergencies for Corona Virus Disease 2019 (COVID-19), PERPU Number 1 of 2020 concerning State Financial Policy and Financial System Stability for Handling Pandemic Corona Virus Disease 2019 (COVID-19) and/or in the context of Facing Threats Endangering the National Economy and/or Financial System Stability, Government Regulation Number 21 of 2020 concerning Large-Scale Social Restrictions in the Context of Accelerating Handling of Corona Virus Disease 2019 (COVID-19), Decree of the Minister of Health of the Republic of Indonesia NumberHK.01.07/MENKES/ 413/2020 concerning Guidelines for the Prevention and Control of Corona Virus Diseases (Covid-19), Circular No.57/ 2020 dated 28 May 2020 concerning the Extension of Work From Home (WFH) for State Civil Servants (ASN) until 4 June 2020, Decree President (KEPPRES) No. 12 of 2020 concerning the Determination of Non-Natural Disaster for the Spread of Corona Virus Disease 2019 (COVID-19) as a National Disaster, and so on. (Yuliana, 2020)

From a number of policies that have been carried out by the government, there has not shown yet a decrease in the number of positive cases of COVID-19, in fact every day there are more positive confirmed cases. If you pay attention to the trend of increasing cases based on time, positive confirmed cases began to rise sharply in July 2020 until now, the peak was on July 9, 2020 with a total of 
2,657 confirmed positive cases scattered throughout Indonesia.

One of the cities in Lampung Province, namely Metro City, does not escape the risk of spreading the COVID19 case. In May 2020, Yosorejo Village was the place where there was the first confirmed case of COVID-19. Until now, there are 5 (five) positive patients in the village. The increase and spread of COVID-19 cases occurred due to the natural nature of the Corona Virus, which is in the form of droplets, which depend on human behavior and the environment. Human mobility and behavior, environmental conditions, and our response will greatly influence the spread of COVID-19. In this case, synergy between the government and the community itself is needed in an effort to break the chain of spreading the COVID19 case in Indonesia, a tactical, innovative, and extra ordinary strategy is needed.

\section{B. Method of Implementation}

The method of activities carried out includes the following:

1 Preparation before the activity:
Before carrying out this activity, several things must be prepared which include:

a. Gathering 7 students of STISIPOL Dharma Wacana to help community service activities.

b. Visiting Kelurahan Yosorejo Kec. Metro Timur Metro City to ask for permission to carry out community service activities.

c. Explaining each jobdesk for all community service committee.

d. Preparing materials and other support needed during community service activities.

2 Implementation

The implementation of community service activities entitled Socialization of Alternative Policy Models in Efforts to Handling the Covid-19 Pandemic Problem in Yosorejo Urban Village, Metro City, was carried out by a lecture and discussion model with activity participants or the local community in Yosorejo Urban Village, Metro City, The implementation of community 
service activities entitled Socialization.

\section{Result and Discussion}

This Community Service activity took place on Monday 31 August 2020. This activity was attended by 19 (nineteen) participants in Yosorejo Village, consisting of village officials and local communities.

After the determination of COVID19 as a pandemic, the reaction of the community has been mixed. There are residents who feel afraid, angry, panic, confused, and sad. Some of the factors causing the increase in cases include the opening of social and economic activities, resulting in high levels of interaction and movement of people. The increase in cases from various types of clusters also has an impact on transmission in the family and community environment. Public saturation in implementing health protocols, especially in wearing masks and maintaining distance is also a factor in the spread of COVID-19 cases.

In this Community Service activity, activities are carried out in the form of socialization, the material presented is about alternative policy models in an effort to deal with the COVID-19 pandemic problem. Until now, the government has taken many policies to break the chain of spreading COVID-19 cases, although they have not significantly reduced the spread of these cases. There are alternative policy options that can be applied in Yosorejo Village, considering that the first confirmed positive case of COVID-19 in Metro City is in this sub-district, even now there are 5 (five) positive confirmed cases, because have ever contacted with the first patient.

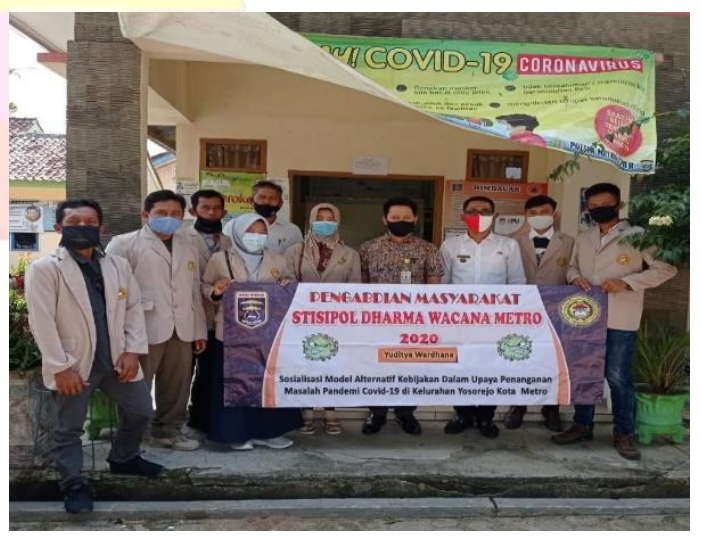

Figure 2. Community Service Team with Head of Yosorejo Urban Village

The first alternative policy model is to form a COVID-19 Alert Village. In fact, the COVID-19 Alert Village hasbegun to be widely applied, 
especially in Java. COVID-19 Alert

Village is a community-based village-

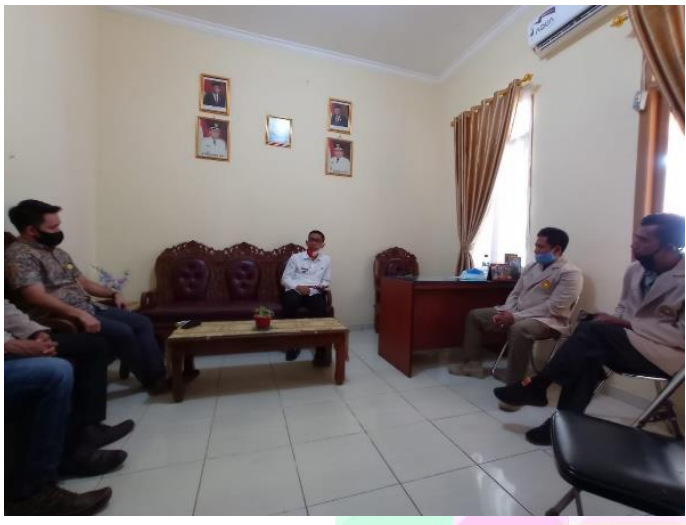

Figure 3. Discussion with the Head of Yosorejo Urban Village before the socialization activity

-that is alerted to help carry out efforts to accelerate the prevention and handling of the spread of COVID-19 within the RW area, with a defined scope of tasks, which is carried out in a participatory and collaborative manner. Some forms of activities that can be carried out in the COVID-19 Alert Village are: Socialization of PHBS (clean and healthy lifestyle), sterilization of public facilities and social facilities, citizen security systems, citizen health information systems, resident logistic barns, environmental volunteers/local participation, and utilize the WhatsApp (WA) Group of residents application WhatsApp (WA).

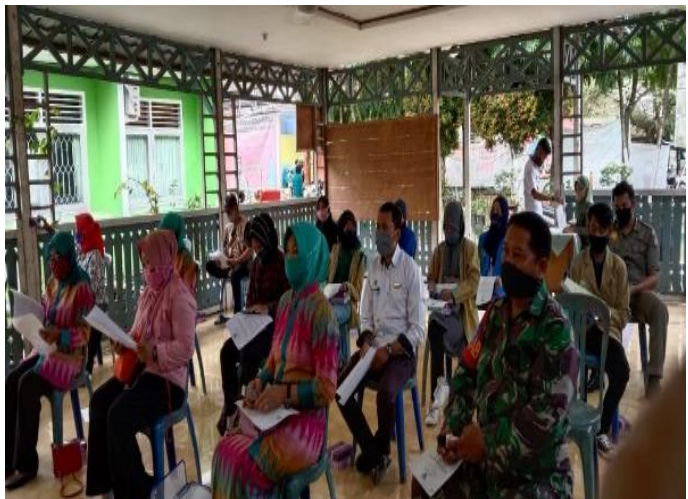

Figure 4. Participants in the socialization activity during the presentation of the material

The second alternative policy model, namely by making Individual, Family and Group Resilience Programs.

The activities that can be carried out are: 1) internalizing the behavior of a clean and healthy life through movement in small groups. 2) development of digital technology-based family and group economic enterprises (Digital Economy).

3) strengthening interpersonal relationships in the family. 4) social protection for families in the form of social insurance and social assistance. 5) increasing self and family resilience in critical conditions through social services.

The third alternative policy model is by utilizing a technology called InaRisk Personal COVID-19. In a Risk Personal 
is an Android and iOS application to find out about the dangers of disasters and risks around us as well as mitigation efforts that we can do independently. This application uses the results developed by BNPB and related Ministries/Institutions as well as support from disaster organizations in Indonesia. By using this application, users will get assessment results in the form of recommendation information and suggestions as well as risk status for COVID-19 with an assessment level: low, medium, high. Another benefit of this application is as a means of educating the public to understand the level of disaster risk where they are.

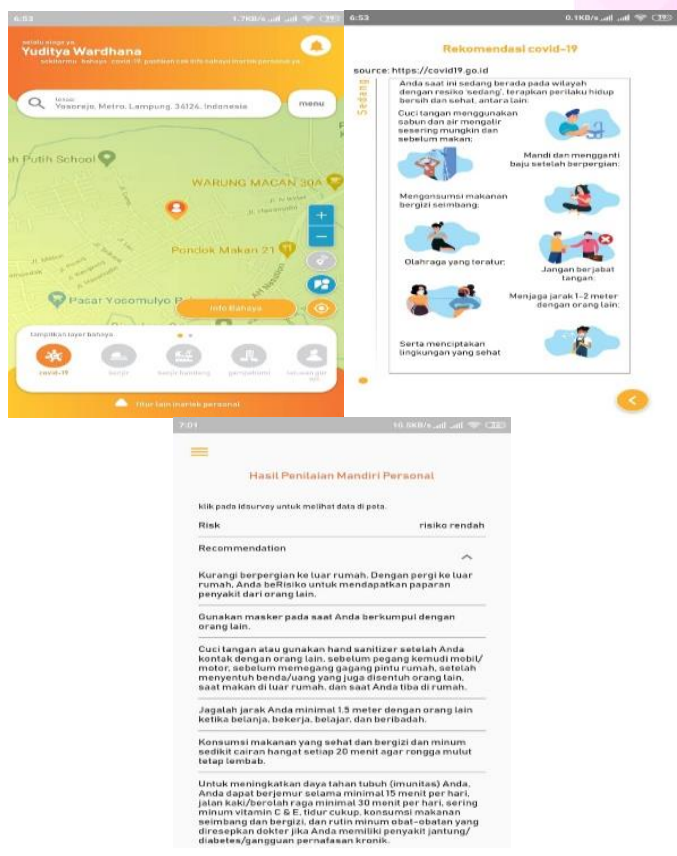

Figure 5. Information display on In a Risk Personal application

\section{Conclusion}

After this service activity is carried out, several conclusions can be drawn including: 1) the people of Yosorejo Village have participated in socialization activities. 2) the community as socialization participants was very enthusiastic in participating in the activity, this was evidenced by the active community in discussions during the activity. 3) the public got new knowledge about alternative policy models in the context of handling the COVID-19 problem.

\section{REFERENCES}

https://www.bnpb.go.id/

https://www.kemkes.go.id/

https://www.who.int/

Handayani, D. (2020). Penyakit Virus Corona 2019. Jurnal Respirologi Indonesia, 40(2), 3-5.

Keputusan Menteri Kesehatan Republik Indonesia Nomor

HK.01.07/MENKES/413/2020 tentang Pedoman Pencegahan dan Pengendalian Corona Virus Diseases (Covid-19) 
PASUNDAN INTERNATIONAL OF COMMUNITY SERVICES JOURNAL(PICS-J) E-ISSN : 2686-3405, ISSN : 2686-2697

VOLUME 02, NO. 02 DECEMBER, 2020

Yuliana. (2020). Corona Virus Diseases

(Covid-19); Sebuah Tinjauan

Literatur. Jurnal Wellness and

Healthy Magazine, 2(1), 5-6. 